\title{
Selecting key areas for conservation at the regional level: the case of the globally 'Near Threatened' Cinereous Vulture Aegypius monachus in south-east Portugal
}

\author{
PEDRO M. LOURENÇO, NUNO CURADO, FILIPA LOUREIRO, \\ ALFONSO GODINO and EDUARDO SANTOS
}

\begin{abstract}
Summary
Since the resources available for nature conservation tend to be very limited, localised conservation actions are often the only feasible management option. Therefore, we must select key areas where these actions will be most effective. Here we used Weighted Linear Combination (WLC) to integrate various variables in a GIS environment and identify key areas for implementing conservation actions benefiting Cinereous Vultures Aegypius monachus in south-east Portugal. Through a bibliographic search, we selected four main variables and sub-variables related to land use, food availability, disturbance and topography. These were weighted for their relative importance using the Analytic Hierarchy Process (AHP) and combined using WLC to obtain suitability maps for the best nesting and foraging sites for Cinereous Vultures. Overall, the study areas show moderate to high suitability as foraging areas for the species, but only a few small patches seem suitable as nesting sites. The use of GIS-based decision support systems, such as WLC, together with an objective method for weighting variables, like the AHP, allows for the integration of large amounts of cartographic information into suitability maps that can easily be used to select key areas for conservation at the regional level.
\end{abstract}

\section{Resumo}

Como os recursos disponiveis para conservação da natureza tendem a ser bastante limitados, acções de conservação localizadas são geralmente a única opção viável. Assim, é necessária a escolha das melhores zonas onde essas acções possam ter eficácia máxima. Neste trabalho usámos Combinação Linear Ponderada (CLP) de forma a integrar várias váriáveis em ambiente SIG para identificar áreas no SE Portugal onde implementar acções de conservação dirigidas ao abutre-preto Aegypius monachus. Com base na bibliografia foram escolhidas quatro variáveis principais e sub-variáveis relacionadas com uso do solo, disponibilidade alimentar, perturbação e topografia. A sua importância relativa foi ponderada usando o Processo Hierárquico Analitico (AHP) e as variáveis foram combinadas através do CLP de forma a obter mapas de adequabilidade para a nidificação e alimentação do abutre-preto. As áreas de estudo mostraram uma adequabilidade moderada a alta no que respeita a zonas de alimentação, mas só algumas pequenas zonas parecem favoráveis à nidificação. $\mathrm{O}$ uso de sistemas de suporte à decisão, como o CLP, aliado a um método objectivo para ponderação das variáveis, como o AHP, permitem integrar grandes quantidades de informação cartográfica na forma de mapas de adequabilidade que podem ser facilmente usados para a selecção das melhores zonas para a conservação à escala regional. 


\section{Introduction}

Conservation efforts often rely on limited economic and human resources, so these must be focused on particular areas or species in order to maximise their efficiency (e.g. Dalton 2000). One of the most pressing issues facing the global conservation community is how to best distribute limited resources between and within regions identified as priorities for biodiversity conservation (Dalton 2000, Wilson et al. 2006). On a broader scale, approaches such as biodiversity hotspots, endemic bird areas and ecoregions are used by international organisations to prioritise conservation efforts (Myers et al. 2000, Halpern 2006, Wilson et al. 2006). The same applies to smaller scales. Localised conservation efforts can be of critical importance and, in many landscapes, the conservation and restoration of small patches is often the only feasible management option (Fischer and Lindenmayer 2002, Hodgkison et al. 2007).

Key areas for conservation can be selected based on species occurrence and abundance, as well as landscape variables (Filipe et al. 2004). When considering the conservation of a particular species, niche variables (Chefaoui et al. 2005) and other factors like human disturbance (e.g. Strittholt and Dellasala 2001) can be modelled together using GIS tools, to select areas where conservation actions will be most effective (Woodhouse et al. 200o). Decision-making on environmental issues is often a process characterised by complexity, uncertainty, multiple and some times conflicting management objectives, as well as the need to integrate numerous and different data types. A GIS-based decision support system should aid and strengthen the process of choice (Sauter 1997, Eastman 1999).

The Cinereous Vulture Aegypius monachus is a globally 'Near Threatened' species with a Eurasian distribution (IUCN 2010). In the Iberian Peninsula, the main stronghold of this species in Europe, the population has recovered in recent years following a dramatic decline that lasted until the 1970 (de la Puente et al. 2007). Despite this, the species is still rare in Spain and virtually absent from Portugal (ICN 2006, Moreno-Opo and Guil 2007). It depends on well-preserved Mediterranean habitats, namely cork oak Quercus suber and holm oak Q. rotundifolia woodlands and dehesas, Mediterranean scrubland and pastures (Carrete and Donázar 2005, Móran-López et al. 2006a, Moreno-Opo et al. 2012). Cinereous Vultures are particularly selective in terms of their breeding sites, requiring undisturbed patches of favourable habitat located in steep hills (Poirazidis et al. 2004, Gavashelishvili et al. 2006, Móran-López et al. 2006a, Moreno-Opo et al. 2012).

Traditionally, Cinereous Vultures fed mostly on wild rabbit Oryctolagus cuniculus carcasses (Costillo et al. 2007a). However, declines in rabbit populations led them to switch their diet, which is currently based on domestic ruminants, and, in some areas, supplemented with wild ungulates (Costillo et al. 2007a,b, Moreno-Opo et al. 2010a). From 2000 onwards, EU health legislation has limited the abandonment of dead animals in the field, resulting in a sudden reduction in food availability for scavengers (Donázar et al. 2009, 2010, Margalida et al. 2010).

Together with illegal poisoning, collisions with electrical infrastructure and habitat loss due to agricultural intensification, the shortage of nesting sites and reduced food availability are the main threats facing Cinereous Vultures in Iberia (Moreno-Opo and Guil 2007) and other large raptors (e.g. Perez-Garcia et al. 2011, Rollan et al. 2010) . These threats may be averted by conservation actions, namely the creation of vulture feeding stations and the construction of artificial nests.

In this paper, we build upon a considerable amount of information regarding the ecological requirements of the Cinereous Vulture to identify favourable areas for the species at the regional level. By crossing different levels of cartographic data, we aim to I) characterise two areas in south-east Portugal in terms of their suitability for the conservation of Cinereous Vultures, and 2) select key areas within these areas where conservation actions can be the most effective.

\section{Methods}

Study area

We worked in two Special Protection Areas (SPAs) in south-east Portugal (Figure 1). The Mourão/Moura/Barrancos SPA is an area of 84,900 ha located along the Portuguese left bank of 


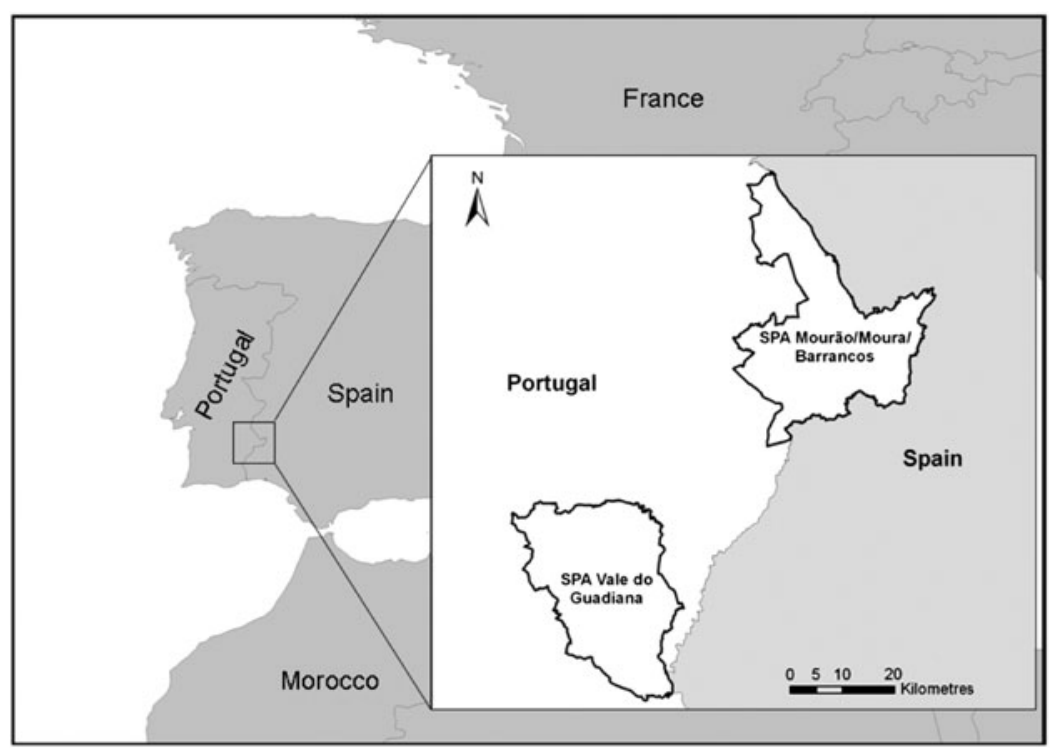

Figure 1. Location of the two study areas in SW Europe, along the border between Portugal and Spain.

the Guadiana River. This heterogeneous area is covered by low density cork and holm oak woodlands (dehesas), extensive cereal crops, permanent pastures and some vineyards and olive groves. The ruggedness of the terrain has allowed some patches of Mediterranean woodland and scrubland to remain relatively undisturbed. The region is sparsely populated and mostly used for extensive farming and livestock breeding, as well as hunting (ICN 2006).

The Vale do Guadiana SPA is an area of 76,500 ha along the Guadiana River. This area is dominated by the Guadiana River and its tributaries, where embedded valleys, surrounded by cliffs, support a rich Mediterranean flora. The landscape is characterised by a mosaic of Cistus dominated scrubland and holm oak dehesas mixed with extensive cereal crops. There are also some well preserved Mediterranean woodlands and traditional olive groves. Human occupation is similar to the other SPA (ICN 2006).

\section{Variable and sub-variable selection and data preparation}

Based on a thorough bibliographic search we selected four main variables: land use, food availability, disturbance and topography. These were then divided into a series of sub-variables (Table 1).

Land use was mapped using aerial photography. To help identify land use types we also used the Portuguese CORINE Land Cover 2006 map (Caetano et al. 2009), the National Forest Inventory $2005 / 2006$ (AFN 2010) and older land use maps for parts of our study areas (Janeiro 2007, Cardoso et al., 2008). This classification was validated with data collected in the field between May and July 2010, by sampling the habitat in eight locations in each $2 \times 2 \mathrm{~km}$ square. We determined habitat type in each of the four quadrants around each location. These habitat data were collected for roughly $85 \%$ of the study area.

To evaluate food availability we used the abundance of both domestic and wild species used by vultures as carrion. We obtained the exact numbers of cows, domestic pigs, sheep and goats per township from the National Veterinary Service (DGV), and calculated their densities to compare townships of different sizes. There was no information on densities of wild rabbit, wild boar Sus 
Table 1 . List of the variables and sub-variables selected for the analysis, and bibliographic references on which the selection was based. References: (1) Fargallo et al. 1998; (2) Donázar et al. 2002; (3) Poirazidis et al. 2004; (4) Carrete and Donázar 2005; (5) Móran-Lopez et al. 2006a; (6) Morán-López et al. 2006b; (7) Moreno-Opo and Guil 2007; (8) Moreno-Opo et al. 2012; (9) Heredia 1996; (10) Costillo et al. 2007a; (11) Costillo et al. 2007b; (12) Gavashelishvili and McGrady 2006; (13) Gavashelishvili et al. 2006; (14) González et al. 2006; (15) Margalida et al. 2011; (16) Bayle 1999; (17) Janss and Ferrer 2001; (18) ICN 2006; (19) Carrete et al. 2007; (20) Hiraldo and Donázar 1989.

\begin{tabular}{|c|c|c|}
\hline Variables & Sub-variables & References \\
\hline Land use & land use & $1,2,3,4,5,6,7,8$ \\
\hline Food availability & $\begin{array}{l}\text { relative abundance of wild rabbit } \\
\text { relative abundance of wild ruminants } \\
\text { relative abundance of wild boar } \\
\text { abundance of sheep and goats } \\
\text { abundance of pigs } \\
\text { abundance of cows }\end{array}$ & $\begin{array}{l}9,10 \\
10,11 \\
10,11 \\
7,10,11 \\
7,10,11 \\
7\end{array}$ \\
\hline Disturbance & $\begin{array}{l}\text { distance to urban areas } \\
\text { distance to paved roads } \\
\text { distance to dirt roads and fire-breaks } \\
\text { distance to power lines } \\
\text { distance to wind turbines }\end{array}$ & $\begin{array}{l}3,5,7,8,12,13,14 \\
3,5,7,8,12,13,14,15 \\
2,3,5,7,8,9,12,13,14,15 \\
7,16,17,18 \\
7,19\end{array}$ \\
\hline Topography & $\begin{array}{l}\text { altitude } \\
\text { slope }\end{array}$ & $\begin{array}{l}6,7,8,13,20 \\
3,6,7,8,13,20\end{array}$ \\
\hline
\end{tabular}

scrofa and wild ruminants (red deer Cerous elaphus, fallow deer Dama dama and European mouflon Ovis aries musimon), so we used relative abundances. The relative abundance of wild rabbit was measured as the number of rabbit latrines found per kilometre (Palomares 2001), for each $2 \times 2 \mathrm{~km}$ UTM square covering the two SPAs. Field work was carried out between May and July 2010 by several teams (including the authors), under the INCOB wild rabbit census project (ICNB 2009). In each $2 \times 2 \mathrm{~km}$ square, four transects of $250 \mathrm{~m}$ were walked in search of latrines. Roughly $85 \%$ of study area was sampled.

The relative abundance of wild boar and the three wild ruminants was based on queries to local game managers, who evaluated the abundance of each species within their land in four categories: $\mathrm{o}$ - absent, 1 - low abundance, 2 - average abundance, 3 - high abundance. The three ruminants were pooled together. These data were included in a digital map of all game reserves. For the few areas where we were unable to obtain data for the wild species we used two approaches. For each $2 \times 2 \mathrm{~km}$ square with no information on wild rabbit we averaged the values of all squares within a $4 \mathrm{~km}$ radius. For the game reserves and the very few non-hunting areas where there was no information on wild boar we assumed a relative abundance of 1 , as the species is very widespread in the region and thus not likely to be anywhere absent (J. Carvalho pers. comm.). In the case of wild ruminants we assumed a relative abundance of $I$ if the area was surrounded by game reserves where at least one of the three species was present, or o if they were absent from the surrounding areas.

All infrastructure and disturbance sources (towns, roads and dirt tracks, power lines and wind turbines) were mapped using scanned topographic maps and aerial photography. Afterwards, we used GIS tools to create buffers of various widths for the different suitability classes (see below).

Topography was analysed using the freely available ASTER Global Digital Elevation Map (http://asterweb.jpl.nasa.gov/gdem.asp). This map has a $30 \mathrm{~m}$ resolution providing altitude data in a $30 \mathrm{~m}$ grid from which the slope was derived using GIS tools.

All GIS work was performed on ArcGIS versions 9 and 10, and we used a grid cell size of $100 \mathrm{x}$ IOO $\mathrm{m}$ for our analysis. 


\section{Data analysis}

We considered that Weighted Linear Combination (WLC) was the most suitable approach. It calculates the suitability of grid cells by weighting and combining multiple variable maps (Eastman 1999). WLC multiplies the cell values of standardised variable maps by the corresponding variable weight, and then adds the weighted values across the different variable maps. Since the weights are all positive or zero and their sum equals to one, the resulting cell values are in the same range as those on the variable maps. The WLC also allows the use of rigid criteria (Boolean masks, e.g. Drobne and Lisec 2009) that may be used to interpret limiting factors that when in place can affect the whole analysis.

In order to calculate the weight of each variable and sub-variable we used the Analytic Hierarchy Process (AHP), a structured technique used to deal with complex decisions (Saaty 1977, 2008). It uses pairwise comparisons of all variables and of all sub-variables within each variable to calculate their weights.

All the values used for variable weights and suitability scores were based on the available literature (see below) and the use of the AHP provides an objective mathematical approach to decide on each weight. When performing pairwise comparisons, we considered a variable proportionately more important than another when all available references support it as more important, proportionately less important when only some of the available references support it as more important, or we would consider both variables equally important if the available references fail to indicate that one variable is more important than the other. To further validate our analysis, all suitability scores and the AHP matrices were thoroughly discussed with a panel of experts who agreed on the final values that were used.

The analytic process followed these steps:

I) we selected all the variables and sub-variables, and defined a number of classes of different suitability within each sub-variable;

2) for each sub-variable, we created a map where the whole study area was classified according to the classes we had defined. This map was converted into a raster layer where each pixel received the suitability score (on a scale of $0-10$ ) that had been defined for its class. For example, on the map for the sub-variable "distance to paved roads" all pixels within $500-1,000 \mathrm{~m}$ of a paved road received a value of 6 . For some sub-variables, two raster layers were made, one for the breeding site selection and another for the foraging site selection, as the suitability scores were different in each case;

3) within each variable all possible pairs of sub-variables were matched in AHP decision matrices. For each pairwise comparison we decided, based on the available bibliography, which sub-variale was more important (if any) and its relative importance received a score of $1-9$ where 1 means equal importance and 9 means extremely more important. We then used the AHP algorithm (see Takahagi 2005) to calculate the sub-variable weights within each variable;

4) The same pairwise comparison was performed for the four main variables, and the AHP algorithm was used to calculate the weight of each variable. This step was perfomed twice, one for the the selection of nesting sites and another for the selection of foraging sites, as some of the pairwise comparisons were different in each case;

5) The WLC calculates the suitability score of each pixel in the final map using the suitability scores of that pixel in each subvariable map multiplied by the variable and subvariable weights. This is done using map algebra in GIS software, with equations similar to this:

$$
\begin{aligned}
S= & W 1(w 1 . s 1+w 2 . s 2)+W 2(w 3 . s 3+w 4 . s 4+w 5 . s 5)+W 3(w 6 . s 6) \\
& +W 4(w 7 . s 7+w 8 . s 8)
\end{aligned}
$$


Where $S$ in the suitability value of the pixel in the final map; $W_{1}, W_{2}, W_{3}$ and $W_{4}$ are the weighs of each of the four main variables; w1, w2, w3, w4, w5, w6, w7 and w8 are the weighs of each of the sub-variables (in this example there are 2 sub-variables within variable 1,3 sub-variables within variable 2 , only 1 sub-variable within variable 3 , and 2 sub-variables within variable 4 ); and $\mathrm{s}_{1}, \mathrm{~s}_{2}, \mathrm{~s}_{3}, \mathrm{~s}_{4}, \mathrm{s5}, \mathrm{s6}, \mathrm{s7}, \mathrm{s} 8$ are the suitability values of that pixel in each of the sub-variable maps.

\section{Variable and sub-variable weights and suitability classes}

Cinereous Vultures show different preferences when choosing nesting and foraging sites (Gavashelishvili and McGrady 2006, Morán-López et al. 2006b, Moreno-Opo et al. 2012). Because of this we had to perform two different analyses, one to select the key areas for nesting and another to select key areas for foraging.

When selecting nesting areas, the most important variable is disturbance, followed by land use and topography (Donázar et al. 2002, Gavashelishvili et al. 2006, Morán-López et al. 2006a, Moreno-Opo et al. 2012). Food availability is less important as vultures can fly tens of kilometres in search of food (Carrete and Donázar 2005). The selection of foraging areas is mostly influenced by food availability and disturbance, while land use and topography are less important (Gavashelishvili and McGrady 2006, Moreno-Opo and Guil 2007). The relative weights of each variable, calculated using AHP, are presented in Table 2.

\section{Land use}

Cinereous Vultures prefer to nest in areas of Mediterranean woodland and dehesas with extensive undergrowth (Donázar et al. 2002, Poirazidis et al. 2004, Morán-López et al. 2006a, Moreno-Opo et al. 2012). Sub-optimal habitats include mature pine forests and open dehesas (Fargallo et al. 1998, Moreno-Opo and Guil 2007). Although scrubland areas are not suitable for nesting due to the lack of large trees, we considered these to have some suitability as the land use classification may describe areas with very low tree densities as scrubland.

Cinereous Vultures show a clear preference for foraging in open dehesas and, to a lesser extent, in pastures and cereal crops (Carrete and Donázar 2005, Moreno-Opo and Guil 2007). Scores for different classes within land use, for nesting and foraging site selection, are presented in Table 3.

\section{Food availability}

At present, the most frequent prey items in the diet of Cinereous Vultures are domestic sheep and goats and wild ruminants (Costillo et al. 2007a,b). Pigs and wild boars are a secondary food source in terms of frequency, and cows are rarely consumed (Costillo et al. $2007 \mathrm{~b}$; Moreno-Opo and Guil 2007). Since there is no published information on the ideal prey densities to support Cinereous Vulture populations, we gave increasing suitability values to each octile of the

Table 2. Relative weights attributed to each variable through the AHP for both nest site and foraging site selection.

\begin{tabular}{lll}
\hline Variables & Weight & \\
\cline { 2 - 3 } & Nest site selection & Foraging site selection \\
\hline Land use & 0.24 & 0.08 \\
Food availability & 0.05 & 0.44 \\
Disturbance & 0.55 & 0.44 \\
Topography & 0.16 & 0.04 \\
\hline
\end{tabular}


Table 3. Suitability scores of the various land use classes for both nest site and foraging site selection.

\begin{tabular}{lcc}
\hline Classes & Nest site selection & Foraging site selection \\
\hline Scrubland & 4 & 4 \\
Open dehesa & 4 & 10 \\
Dehesa with undergrowth & 10 & 4 \\
Mediterranean woodland & 10 & 0 \\
Young pine forest & o & 2 \\
Mature pine forest & 6 & 2 \\
Young Eucalyptus plantation & 0 & 2 \\
Mature Eucalyptus plantation & 0 & 2 \\
Olive grove & 0 & 4 \\
Vineyard & 0 & 4 \\
Orchard & 0 & 4 \\
Dry crop land & 0 & 8 \\
Irrigated crop land & 0 & 4 \\
Pasture & 0 & 8 \\
Urban area & 0 & 0 \\
Water body & 0 & 0 \\
\hline
\end{tabular}

distribution of relative or absolute abundances of each prey species in our study area (Table 4). By using the octile distribution instead of any parametric measures, we hoped to avoid problems caused by any skewed distribution of prey abundance.

The sub-variable weights and suitability classes for food availability were equal for both the nest site and the foraging site selection analyses (Table 4).

\section{Disturbance}

The most important source of human disturbance for Cinereous Vultures is paved roads, followed by urban areas (Gavashelishvili and McGrady 2006, Moreno-Opo and Guil 2007). Dirt tracks and fire-breaks have a smaller impact on the species (Moreno-Opo and Guil 2007) (Table 5). The distance to power lines and wind turbines poses a risk of increased mortality, which will be dealt with in the next section. In terms of simple disturbance, power lines and wind turbines are likely less serious than paved roads and urban areas, but wind turbines are known to cause considerable disturbance in other vulture species (Carrete et al. 2007) (Table 5). Moreno-Opo and Guil (2007) indicate a minimum of $250 \mathrm{~m}$ as the recommended distance for dirt tracks, and $500 \mathrm{~m}$ for paved roads and power lines (but see González et al. 2006, Margalida et al. 2012). Ideally these distances should be twice as large (Moreno-Opo and Guil 2007). Wind turbines are known to cause some disturbance up to a distance of $3,000 \mathrm{~m}$, but a distance of $1,000 \mathrm{~m}$ may already lessen the

Table 4. Weight attributed to each food availability sub-variable through the AHP and suitability scores of the various classes (octiles). The classes and their suitability are the same for all sub-variables.

\begin{tabular}{llll}
\hline Sub-variable & Weight & Classes & Suitability score \\
\hline Abundance of wild rabbit & 0.36 & $1^{\text {st }}$ octile & 0 \\
Abundance of wild ruminants & 0.22 & $2^{\text {nd }}$ octile & 2 \\
Abundance of wild boar & 0.10 & $3^{\text {rd }}$ octile & 4 \\
Abundance of sheep and goats & 0.22 & $4^{\text {th }}$ octile & 4 \\
Abundance of pigs & 0.07 & $5^{\text {th }}$ octile & 6 \\
Abundance of cows & 0.03 & $6^{\text {th }}$ octile & 6 \\
& & $7^{\text {th }}$ octile & 8 \\
\hline
\end{tabular}


Table 5. Weight attributed to each disturbance sub-variable through the AHP and suitability scores of the various classes.

\begin{tabular}{|c|c|c|c|}
\hline Sub-variable & Weight & Classes & Suitability score \\
\hline Distance to urban areas & 0.25 & $\begin{array}{c}0-500 \mathrm{~m} \\
500-1,000 \mathrm{~m} \\
1,000-1,500 \mathrm{~m} \\
>1,500 \mathrm{~m}\end{array}$ & $\begin{array}{r}0 \\
2 \\
6 \\
10\end{array}$ \\
\hline Distance to paved roads & 0.50 & $\begin{array}{c}\quad 0-500 \mathrm{~m} \\
500-1,000 \mathrm{~m} \\
>1,000 \mathrm{~m}\end{array}$ & $\begin{array}{l}0 \\
6 \\
10\end{array}$ \\
\hline $\begin{array}{l}\text { Distance to dirt tracks } \\
\text { and fire-breaks }\end{array}$ & 0.07 & $\begin{array}{c}0-250 \mathrm{~m} \\
250-500 \mathrm{~m} \\
500-1,000 \mathrm{~m}\end{array}$ & $\begin{array}{r}2 \\
6 \\
10\end{array}$ \\
\hline Distance to power lines & 0.07 & $\begin{array}{c}0-500 \mathrm{~m} \\
500-1,000 \mathrm{~m} \\
>\quad 1,000 \mathrm{~m}\end{array}$ & $\begin{array}{r}0 \\
6 \\
10\end{array}$ \\
\hline Distance to wind turbines & 0.11 & $\begin{array}{l}0-1,000 \mathrm{~m} \\
1,000-3,000 \mathrm{~m} \\
>3,000 \mathrm{~m}\end{array}$ & $\begin{array}{r}0 \\
6 \\
10\end{array}$ \\
\hline
\end{tabular}

disturbance (Moreno-Opo and Guil 2007, Carrete et al. 2007). Urban areas do not seem to cause disturbance at distances over 1,500 m (Fargallo et al. 1998) (Table 5).

We considered that the sub-variable weights and the suitability classes for disturbance were equal for both the nest site and foraging site selection analyses (Table 5).

\section{Topography}

Slope is the most important sub-variable in terms of nest site selection (Moreno-Opo et al. 2012). Cinereous Vultures tend to nest in areas with slopes above $10^{\circ}$, and ideally above $30^{\circ}$ (Poirazidis et al. 2004, Morán-López et al. 2006a). Altitude is of secondary importance, although most colonies are located above $400 \mathrm{~m}$ (Gavashelishvili et al. 2006 Morán-López et al. 2006a). The slope is not a serious issue for foraging site selection, but we considered near vertical slopes $\left(>45^{\circ}\right)$ to be limiting. Table 6 presents the weights of both topographic sub-variables and the various suitability classes.

Table 6. Weight attributed to each topography sub-variable through the AHP and suitability scores of the various classes, for both nest site $(\mathrm{N})$ and foraging site selection $(\mathrm{F})$.

\begin{tabular}{|c|c|c|c|c|c|}
\hline \multirow[t]{2}{*}{ Sub-variable } & \multicolumn{2}{|c|}{ Weight } & \multirow[t]{2}{*}{ Classes } & \multicolumn{2}{|c|}{ Suitability scores } \\
\hline & $\mathrm{N}$ & F & & $\mathrm{N}$ & $\mathrm{F}$ \\
\hline \multirow[t]{3}{*}{ Altitude } & 0.11 & 0.11 & $\mathrm{O}-200 \mathrm{~m}$ & 6 & 6 \\
\hline & & & $200-400 \mathrm{~m}$ & 8 & 10 \\
\hline & & & $>400 \mathrm{~m}$ & 10 & 10 \\
\hline \multirow[t]{5}{*}{ Slope } & 0.89 & 0.89 & $0-10^{\circ}$ & o & 10 \\
\hline & & & $10-20^{\circ}$ & 4 & 10 \\
\hline & & & $20-30^{\circ}$ & 8 & 10 \\
\hline & & & $30-45^{\circ}$ & 10 & 10 \\
\hline & & & $>45^{\circ}$ & 4 & 6 \\
\hline
\end{tabular}




\section{Limiting factors}

Some disturbance factors pose such a high level of disturbance, or increased risk of mortality, that the grid cells where these occur should always be considered unsuitable for Cinereous Vulture conservation actions. These included all areas within $500 \mathrm{~m}$ of paved roads, power lines and urban areas, as well as areas within $1,000 \mathrm{~m}$ of wind turbines. In the nest site selection analysis the same was done for all grid cells with land use types that have no large trees and are thus unsuitable as nesting sites. These grid cells where therefore included in a Boolean mask where every grid cell had a final suitability value of $o$.

\section{Results}

The nest and foraging site selection analyses provided very different results. Whereas in the first one only $17 \%$ of the 160,302 grid cells showed moderate to high suitability (values $>6$ ) as nesting sites for Cinereous Vultures (Fig. 2), the second one indicated that $50 \%$ of grid cells showed moderate to high suitability as foraging sites (Figure 3). The difference is smaller if we just consider the cells with high suitability (values $>8$ ), which are only $6 \%$ for nest site selection, and II\% for foraging sites.

The proportion of grid cells with high suitability for nesting is similar in both SPAs (5.7-6.3 \%), but the Vale do Guadiana SPA has a larger proportion of high suitability cells for foraging than the Mourão/Moura/Barrancos SPA (15.2 \% vs. $7 \cdot 3 \%$ ).

\section{Mourão/Moura/Barrancos SPA}

The grid cells with high suitability for nest sites are mostly found along a central line roughly separating the northern and southern parts of the area (Fig. 2A). For foraging site selection, most of this SPA is covered by large patches of moderate to high suitability cells divided by low

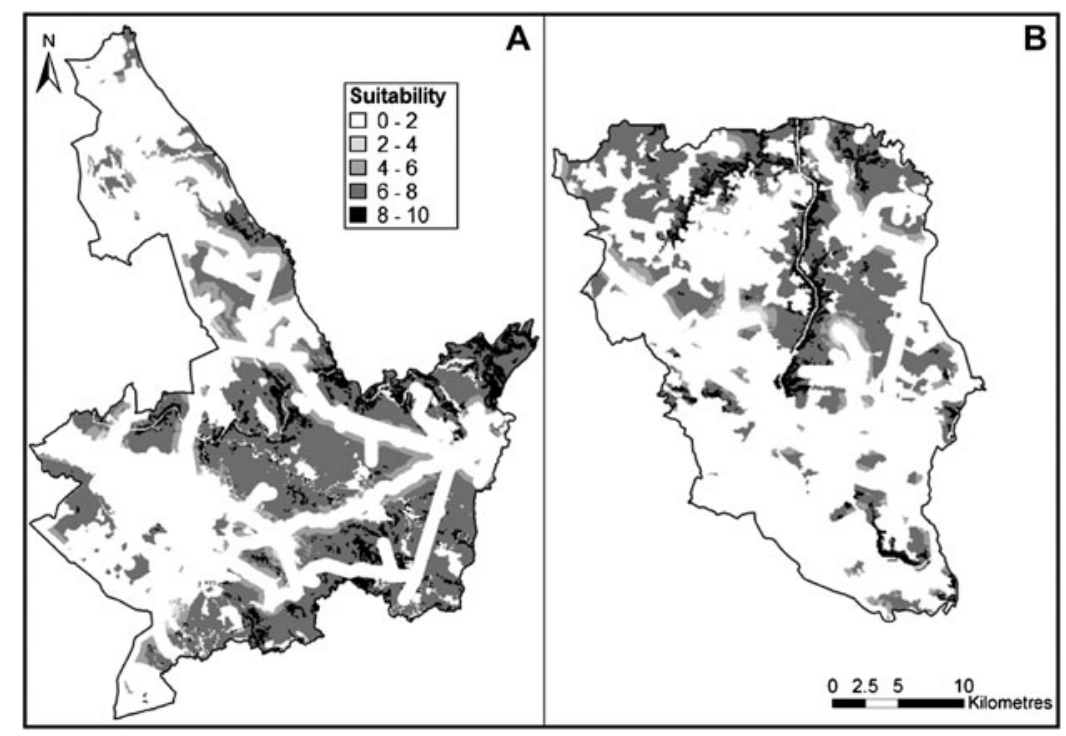

Figure 2. Predictive map of nest suitability for the Mourão/Moura/Barrancos SPA (A) and the Vale do Guadiana SPA (B). 


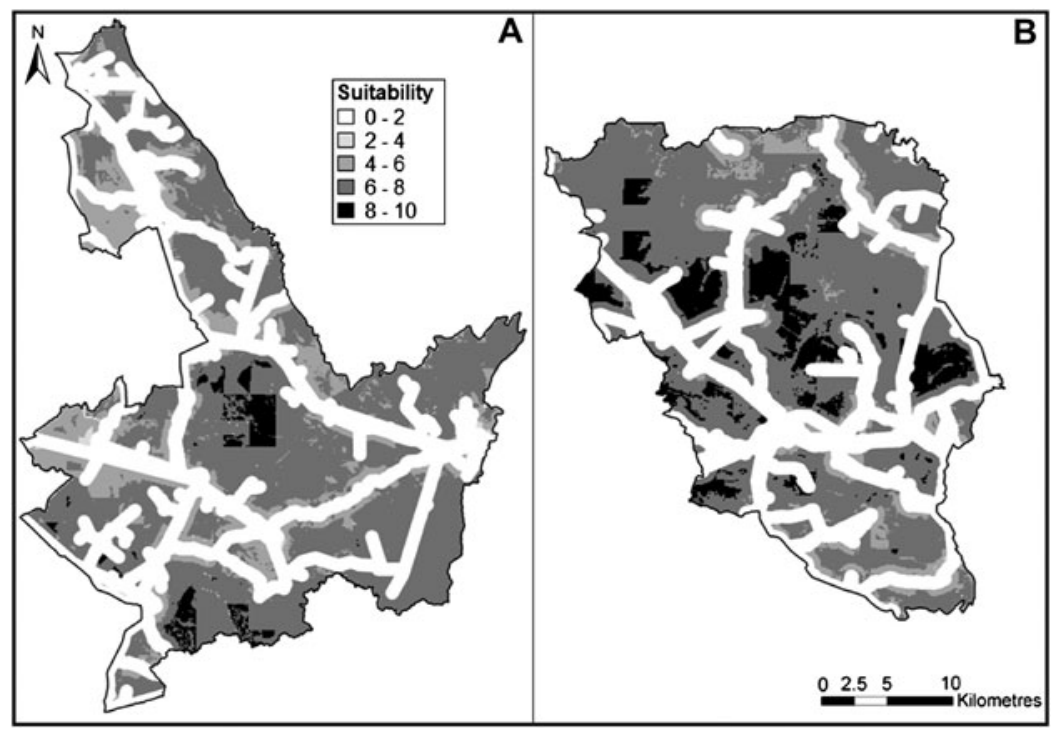

Figure 3. Predictive map of foraging suitability for the Mourão/Moura/Barrancos SPA (A) and the Vale do Guadiana SPA (B).

suitability areas surrounding the roads, power lines and urban areas. Patches of high suitability grid cells are found in the central and southern parts of the area (Figure $3 \mathrm{~A}$ ).

\section{Vale do Guadiana SPA}

The few patches with high suitability for nest sites are mostly found in the northern half of the SPA. There are two other small patches of high suitability, one in the western border of the SPA and another along the southern part of the Guadiana River (Figure 2B). Most of this SPA is covered with cells of moderate to high suitability for foraging. These are mixed with low suitability cells along the roads, power lines and urban areas. There are patches of high suitability cells in the central, western and north-western parts of the area (Figure ${ }_{3} \mathrm{~B}$ ).

\section{Discussion}

This kind of study is always limited by the availability of information on the ecological requirements of the study species. Our analyses were built on a considerable body of data gathered on the ecological requirements of Cinereous Vultures in different parts of their European range (e.g. Poirazidis et al. 2004, Gavashelishvili et al. 2006, Morán-López et al. 2006b, Moreno-Opo et al. 2012), which gives us confidence that our work presents a valid contribution to the conservation of this species.

Our analyses were based on the four main variables previously described as significant for Cinereous Vultures: land use, food availability, disturbance and topography. These variables have a different contribution whether we are considering foraging site selection or nest site selection (e.g. Gavashelishvili and McGrady 2006, Morán-López et al. 2006a). In terms of foraging site selection we found that the two SPAs studied show good suitability, with large patches of moderate to high suitability cells in both cases. This high suitability was mostly due to the availability of sheep, goats and wild ruminants. Wild rabbits were only abundant in some parts of the Vale do Guadiana SPA. 
The short distance to paved roads, power lines and urban areas limited the suitability of many areas on the map. Land use and topography were less important for selecting foraging sites.

The Cinereous Vulture has much stricter requirements in terms of the land use, topography and disturbance near their nest sites (Donázar et al. 2002, Gavashelishvili et al. 2006, Morán-López et al. 2006a). There were only a few areas with moderate to high suitability, located in steep slopes along rivers and hill sides, where there were large trees and sufficient undergrowth, and where the distance to disturbance sources was sufficiently large. Food availability had little impact on nest site suitability.

According to our results, several conservation measures may be applied in these SPAs to improve Cinereous Vulture populations in Portugal, namely the construction of artificial nests and the creation of vulture feeding stations. These actions should be coupled with management agreements with land owners, and awareness actions, to minimise human disturbance in key areas and create the necessary conditions for the species to naturally recolonise the region.

Each SPA has three main areas where artificial nests could be built. Since the Cinereous Vulture is loosely colonial (Moreno-Opo and Guil 2007), each of these six areas could function as a small colony, and form the initial stage of future colonies in the region. As for feeding stations, the presence of a single large location where carrion is made available increases the predictability of food, reducing vulture search efficiency (Deygout et al. 2009) while also posing a larger risk of spreading disease (Robb et al. 2008, Moreno-Opo et al. 2010b). This concentration of food would also allow the more dominant or abundant species, such as Eurasian Griffon Gyps fulvus, to monopolise the food, limiting the benefits of the feeding station for rarer species, such as the Cinereous Vulture (Cortés-Avizanda et al. 2010). A network of smaller feeding stations would be more beneficial while also reducing transportation costs and $\mathrm{CO}_{2}$ emissions, and allowing a larger number of farmers to benefit from the service provided by vultures (Moreno-Opo et al. 201ob, Dupont et al. 2011, Margalida et al. 2012). Since there are several wide areas suitable as feeding locations, the region can support a network of small feeding stations that would compensate the lack of food caused by the health legislation. This may attract Cinereous Vultures into the region and reduce the risk of illegal poisoning as one of the main factors affecting non-natural mortality in this and other carrion-eating species (e.g. Hernández and Margalida 2008).

Artificial nests can tackle the problem of low availability of good nesting trees (Galán et al. 2002). However, it is not yet clear if they can induce the settlement of new breeding colonies in areas where the species became extinct. Still, since the species was once common breeding within our study area, and the presence of Cinereous Vultures is still frequent (the nearest Spanish colonies are just $20 \mathrm{~km}$ away from the border), we have reasons to believe that these actions may facilitate the establishment of breeding colonies in the region. Furthermore, the fact that the Iberian population is increasing suggests that such a range expansion is likely to occur in the near future.

These two main conservation actions should be compatible with further actions, namely increasing the local population of wild rabbits and working with stakeholders to maintain and improve Mediterranean woodlands (Moreno-Opo and Guil 2007). Also, feeding stations are not a real solution for the long-term conservation of scavengers, as they make these species dependent on management actions (Donázar et al. 2009, Margalida et al. 2010). It is important to continue efforts towards relaxing the current European legislation on the management and disposal of animal carcasses, so they can once again become naturally available for vultures without formal feeding stations (Margalida et al. 2010). The new regulations (CE $1069 / 2009$ and RD 1632/2011), has already taken some steps in that direction, but much work is still needed to achieve this goal (Margalida et al. 2010, 2012).

The method used here, combining WLC and AHP, allows the combination of different levels of cartographic data, while providing the means to make objective decisions based on information that can be subjective to some extent (Eastman 1999, Saaty 2008). The AHP provides a relatively simple, but robust method for deciding the weights that each variable should be given, while the WLC allows for these weights to be applied on multiple variables. Together, these approaches allow a very large amount of information to be integrated into a final suitability map that can easily be interpreted and used to plan conservation actions. The availability of a large set of 
bibliographic information on the ecological requirements of Cinereous Vultures gives strength to our results, as they are based on a very solid body of evidence (see review in Moreno-Opo et al. 2012). Also, to make our analysis more transparent, all the decision matrices used for the AHP, as well as the final variable weights, were carefully discussed with a group of independent experts, which provided another way to reduce subjectivity.

These two analytic approaches have been used in various fields (see review in Vaidya and Kumar 2006), ranging from geology and risk management (e.g. Ayalew et al. 2004), urban planning and waste management (e.g. Mahini and Gholamalifard 2006), engineering (e.g. Lai et al. 2002), health and epidemiology (e.g. Clements et al. 2006) and environmental impact assessment (e.g. Kiker et al. 2005). Their use in planning and prioritising conservation actions has been more limited, but some examples include deciding regional re-vegetation priorities (Zerger et al. 2009), incorporating stakeholder preferences into forest and wetland management (Ananda and Herath 2003, Herath 2004) or weighting conflicting objectives in fishery management (Leung et al. 1998). These methods have been evaluated as very useful for increasing the transparency and the credibility of decision processes and are particularly efficient at regional or national levels.

To our knowledge there are no previous studies using these methods to select key areas for the conservation of a particular species. Although this method is limited by the availability of detailed data on the ecological requirements of a species, provided this information is available it should be a very useful method for planning the conservation of other endangered species at the regional level.

\section{Acknowledgements}

We would like to thank the several agencies and organizations that provided a large part of the cartographic data, namely ADS Mourão (Associação de Defesa Sanitária), AFN (Autoridade Florestal Nacional), DGV (Direcção Geral de Veterinária), EDP (Energias de Portugal), ICNB (Instituto de Conservação da Natureza e Biodiversidade), REN (Rede Eléctrica Nacional), the teams involved in the wild rabbit census of the INCOB project and all the town halls within the study area. The analyses we present were thoroughly discussed and improved upon by a panel of experts, whom we would like to thank. They were P. Rocha and A. Monteiro from ICNB, C. Pacheco, J. M. Palmeirim from the University of Lisbon, R. Arenas from the Consejería de Medio Ambiente de Andalucía and J. de la Puente from SEO/Birdlife. We would also like to thank two anonymous referees and A. Margalida for the revisions made on an earlier version of the manuscript. This study was conducted as part of the "LIFE Habitat Lince Abutre - Enhancing habitat for Iberian lynx and black vulture in SE Portugal" project which is co-funded by the LIFE Nature programme of the European Commission, by Fauna \& Flora International and by ICNB.

\section{References}

AFN (2010) Inventário florestal nacional Portugal continental. Lisboa, Portugal: Autoridade Florestal Nacional. (Technical report).

Ananda, J. and Herath, G. (2003) The use of the Analytic Hierarchy Process to incorporate stakeholder preferences into regional forest planning. Forest Policy Econ. 5: 13-26.

Ayalew, L., Yamagishi, H. and Ugawa, N. (2004) Landslide susceptibility mapping using GISbased weighed linear combination, the case in the Tsugawa area of the Agano River, Niigata Prefecture, Japan. Landslides 1: 73-81.
Bayle, P. (1999) Preventing bird of prey problems at transmission lines in western Europe. J. Raptor Res. 33: 43-48.

Caetano, M., Nunes, V. and Nunes, A. (2009) CORINE land cover 2006 for continental Portugal. Lisboa, Portugal: Instituto Geográfico Português. (Technical report).

Cardoso, A. C., Rocha, P., Fialho, S., Farinha, J. C., Rito, P. and Silva, E. (2008) Plano de gestão do vale do Guadiana - Parque Natural do Vale do Guadiana e Zona de Protecção Especial do Vale do Guadiana. 
Mértola, Portugal: Instituto de Conservação da Natureza e Biodiversidade.

Carrete, M. and Donázar, J. A. (2005) Application of central place foraging theory shows the importance of Mediterranean dehesas for the conservation of the Cinereous Vulture, Aegypius monachus. Biol. Conserv. 126: 582-590.

Carrete, M., Grande, J. M., Tella, J. L., Sánchez-Zapata, J. A., Donázar, J. A., Díaz-Delgado, R. and Romo, A. (2007) Habitat, human pressure, and social behaviour: partialling out factors affecting largescale territory extinction in an endangered vulture. Biol. Conserv. 136: 143-154.

Chefaoui, R. M., Hortal, J. and Lobo, J. M. (2005) Potential distribution modelling, niche characterization and conservation status assessment using GIS tools: a case study of Iberian Copris species. Biol. Conserv. 122: 327-338.

Clements, A. C. A., Pfeiffer, D. U. and Martin, V. (2006) Application of knowledge-driven spatial modelling approaches and uncertainty management to a study of Rift Valley fever in Africa. Int. J. Health Geogr. 5: 57.

Cortés-Avizanda, A., Carrete, M. and Donázar, J. A. (2010) Managing supplementary feeding for avian scavengers: Guidelines for optimal design using ecological criteria. Biol. Conserv. 143: 17071715 .

Costillo, E., Corbacho, C., Morán, R. and Villegas, A. (2007a) The diet of the black vulture Aegypius monachus in response to environmental changes in Extremadura (1970-2000). Ardeola 42: 197-204.

Costillo, E., Corbacho, C., Morán, R. and Villegas, A. (2007b) Diet plasticity of Cinereous Vulture Aegypius monachus in different colonies in the Extremadura (SW Spain). Ardea 95: 201-211.

Dalton, R. (2000) Biodiversity cash aimed at hotspots. Nature 406: 818.

de la Puente, J., Moreno-Opo, R. and del Moral, J. C. (2007) El buitre negro en España. Censo nacional (2006). Seguimento de Aves, 13: 1-118. Madrid, Spain: SEO/BirdLife.

Deygout, C., Gault, A., Sarrazin, F. and Bessa-Gomes, C. (2009) Modeling the impact of feeding stations on vulture scavenging service efficiency. Ecol. Model. 220: 18261835 .

Donázar, J. A., Blanco, G., Hiraldo, F., Soto-Largo, E. and Oria, J. (2002) Effects of forestry and other land-use practices on the conservation of Cinereous Vultures. Ecol. Appl. 12: 1445-1456.

Donázar, J. A., Margalida, A., Carrete, M. and Sánchez-Zapata, J. A. (2009) Too sanitary for vultures. Science 326: 664.

Donázar, J. A., Cortés-Avizanda, A. and Carrete, M. (2010) Dietary shifts in two vultures after the demise of supplementary feeding stations: consequences of the EU sanitary legislation. Eur. J. Wildl. Res. 54: 613-621.

Drobne, S. and Lisec, A. (2009) Multi-attribute decision analysis in GIS: weighted linear combination and ordered weighted averaging. Informatica 33: 459-474.

Dupont, H., Mihaub, J. B., Becu, N. and Sarrazin, F. (2011) Modelling interactions between scavenger behaviour and farming practices: Impacts on scavenger population and ecosystem service efficiency. Ecol. Model. 222: 982-992.

Eastman, J. R. (1999) Multi-criteria evaluation and GIS. In P. A. Longley, M. F. Goodchild, D. J. Maguire and D. W. Rhind, eds. Geographic Information Systems: Principles and technical issues (Vol. I). $2^{\text {nd }}$ edition. New York, USA: John Wiley and Sons, Inc. Fargallo, J. A., Blanco, G. and Soto-Largo, E. (1998) Forest management effects on nesting habitat selected by Eurasian black vultures (Aegypius monachus) in central Spain. J. Raptor Res. 32: 202-207.

Filipe, A. F., Marques, T. A., Seabra, S., Tiago, P., Ribeiro, F., Moreira da Costa, L., Cowx, I. G. and Collares-Pereira, M. J. (2004) Selection of priority areas for fish conservation in Guadiana River basin, Iberian Peninsula. Conserv. Biol. 18: 189-200.

Fischer, J. and Lindenmayer, D. B. (2002) Small patches can be valuable for biodiversity conservation: two case studies on birds in south-eastern Australia. Biol. Conserv. 106: 129-136.

Galán, R., Segovia, C., Alés, E. E. and Martínez, M. A. (2002) El Proyecto para la recuperación de la colonia del buitre negro de la Sierra de las Contiendas. 
Resultados del año 2000. Andalus 80: 13-15.

Gavashelishvili, A. and McGrady, M. J. (2006)

Geographic information system-based modelling of vulture response to carcass appearance in the Caucasus. J. Zool. 269: 365-372.

Gavashelishvili, A., McGrady, M. J. and Javakhishvili, Z. (2006) Planning the conservation of the breeding population of Cinereous Vultures Aegypius monachus in the Republic of Georgia. Oryx 40: 76:83.

González, L. M., Arroyo, B. E., Margalida, A., Sánzhez, R. and Oria, J. (2006) Effect of human activities on the behaviour of breeding Spanish imperial eagles (Aquila adalberti): management implications for the conservation of a threatened species. Anim. Conserv. 9: 85-93.

Halpern, B. S. (2006) Gaps and mismatches between global conservation priorities and spending. Conserv. Biol. 20: 56-64.

Herath, G. (2004) Incorporating community objectives in improved wetland management: the use of the analytic hierarchy process. J. Environ. Manage. 70: 263-273.

Hernández, M. and Margalida, A. (2008) Pesticide abuse in Europe: effects on the Cinereous Vulture (Aegypius monachus) population in Spain. Ecotoxicology 17: 264-272.

Heredia, B. (1996) Action plan for the Cinereous Vulture (Aegypius monachus) in Europe. Pp. $147-158$ in B. Heredia, L. Rose and M. Painter, eds. Globally threatened birds in Europe: action plans. Strasbourg, France: Council of Europe and BirdLife International.

Hiraldo, F. and Donázar, J. A. (1989) Foraging time in the Cinereous Vulture Aegypius monachus: seasonal and local variations and influence of weather. Bird Study 37: 128132.

Hodgkison, S., Hero, J. -M. and Warnken, J. (2007) The efficacy of small-scale conservation efforts, as assessed on Australian golf courses. Biol. Conserv. 135: 576586.

ICN (2006) Plano sectorial da Rede Natura 200o. Lisboa, Portugal: Instituto da Conservação da Natureza.

ICNB (2009) Projecto INCOB - rede de monitorização de coelho-bravo. Metodologia e proposta de actuações. Lisboa, Portugal:
Instituto de Conservação da Natureza e da Biodiversidade. (Unpublished report).

IUCN (2010) IUCN Red list of threatened species. Version 2010.4. www.iucnredlist. org. downloaded on May 2011.

Janeiro, C. (2007) Adequabilidade e perspectivas de gestão de habitat para o lince-ibérico Lynx pardinus no sitio Moura-Barrancos. Msc thesis. University of Évora, Portugal.

Janss, G. F. E. and Ferrer, M. (2001) Avian electrocution mortality in relation to pole design and adjacent habitat in Spain. Bird Conserv. Internatn. 11: 3-12.

Kiker, G. A., Bridges, T. S., Varghese, A., Seager, T. P. and Linkov, I. (2005) Application of multicriteria decision analysis in environmental decision making. Integ. Environ. Assess. Manage. 1: 95-108.

Lai, V., Wong, B. K. and Cheung, W. (2002) Group decision making in a multiple criteria environment: a case using the AHP in the software selection. Eur. J. Oper. Res. 137: 134-144.

Leung, P. S., Muraoka, J., Nakamoto, S. T. and Pooley, S. (1998) Evaluating fisheries management options in Hawaii using analytic hierarchy process (AHP). Fisheries Res. 36: 171-183.

Mahini, A. S. and Gholamalifard, M. (2006) Siting MSW landfills with a weighed linear combination methodology in a GIS environment. Int. J. Environ. Sci. Tech. 3: 435445 .

Margalida, A., Donázar, J. A., Carrete, M. and Sánchez-Zapata, J. A. (2010) Sanitary versus environmental policies: fitting together two pieces of the puzzle of European vulture conservation. J. Appl. Ecol. 47: 931935.

Margalida, A., Moreno-Opo, R., Arroyo, B. E. and Arredondo, A. (2011) Reconciling the conservation of endangered species with economically important anthropogenic activities: interactions between cork exploitation and the Cinereous Vulture in Spain. Anim Conserv. 14: 167-174.

Margalida, A., Carrete, M., Sánchez-Zapata, J. A. and Donázar, J. A. (2012) Good news for European vultures. Science 335: 284

Morán-López, R., Sánchez-Guzmán, J. M., Borrego, E. C. and Sánchez, A. V. (2006a) Nest-site selection of endangered Cinereous 
Vulture (Aegypius monachus) populations affected by anthropogenic disturbance: present and future conservation implications. Anim. Conserv. 9: 29-37.

Morán-López, R., Sánchez, J. M., Costillo, E., Corbacho, C. and Villegas, A. (2006b) Spatial variation in anthropic and natural factors regulating the breeding success of the Cinereous Vulture (Aegypius monachus) in the SW Iberian Peninsula. Biol. Conserv. 130: 169-182.

Moreno-Opo, R. and Guil, F. (coordinators) (2007) Manual de gestión del hábitat y de las poblaciones buitre negro en España. Madrid, Spain: Dirección General de la Biodiversidad. Ministerio de Medio Ambiente.

Moreno-Opo, R., Arredondo, A. and Guil, F. (2010a) Foraging range and diet of Cinereous Vulture Aegypius monachus using livestock resources in central Spain. Ardeola 57: III-119.

Moreno-Opo, R., Margalida, A., Arredondo, A., Guil, F., Mártin, M., Higuero, R., Soria, C. and Guzmán, J. (2010b) Factors influencing the presence of the Cinereous Vulture Aegypius monachus at carcasses: food preferences and implications for the management of supplementary feeding sites. Wildl. Biol. 16: 25-34.

Moreno-Opo, R., Fernández-Olalla, M., Margalida, A., Arredondo, A. and Guil, F. (2012) Effect of methodological and ecological approaches on heterogeneity of nest-site selection of a long-lived vulture. PLOS ONE: e33469. doi: 10.1371/journal.pone.0033469.

Myers, N., Mittermeier, R. A., Mittermeier, C. G., da Fonseca, G. A. B. and Kent, J. (2000) Biodiversity hotspots for conservation priorities. Nature 403: 853-858.

Palomares, F. (2001) Comparison of 3 methods to estimate rabbit abundance in a Mediterranean environment. Wildl. Soc. Bull. 29: $578-585$.

Pérez-García, J. M., Botella, F., SánchezZapata, J. A. and Moleón, M. (2011) Conserving outside protected areas: edge effects and avian electrocutions in the periphery of Special Protection Areas. Bird Conserv. Internatn. 21: 296-302.
Poirazidis, K., Goutner, V., Skartsi, T. and Stamou, G. (2004) Modelling nesting habitat as a conservation tool for the Eurasian black vulture (Aegypius monachus) in Dadia Nature Reserve, north-eastern Greece. Biol. Conserv. 118: 235-248.

Robb, G. N., McDonald, R. A., Chamberlain, D. E. and Bearhop, S. (2008) Food for thought: supplementary feeding as a driver of ecological change in avian populations. Front. Ecol. Environ. 6: 476-484.

Rollan, A., Real, J., Bosch, R., Tinto, A., Hernandez-Matias, A. (2010) Modelling the risk of collision with power lines in Bonelli's Eagle Hieraaetus fasciatus and its conservation implications. Bird Conserv. Internatn. 20: 279-294.

Saaty, T. L. (1977) A scaling method for priorities in hierarchical structures. J. Math. Psychol. 15: 231-281.

Saaty, T. L. (2008) Decision making with the analytical hierarchy process. Int. J. Services Sci. 1: 83-98.

Sauter, V. L. (1997) Decision support systems. New York, USA: John Wiley \& Sons Inc.

Strittholt, J. R. and Dellasala, D. A. (200I) Importance of roadless areas in biodiversity conservation in forested ecosystems: case study of the Klamath-Siskiyou ecoregion of the United States. Conserv. Biol. 15: 17421754 .

Takahagi, E. (2005) AHP (Analytical Hierarchy Process) calculation software by CGI. www.isc.senshu-u.ac.jp/ thco456/EAHP/ AHPweb.html (accessed in Jan 2011).

Vaidya, O. S. and Kumar, S. (2006) Analytic hierarchy process: an overview of applications. Eur. J. Oper. Res. 169: 1-29.

Wilson, K. A., McBride, M. F., Bode, M. and Possingham, H. P. (2006) Prioritizing global conservation efforts. Nature 440: 337-340.

Woodhouse, S., Lovett, A., Dolman, P. and Fuller, R. (2000) Using a GIS to select priority areas for conservation. Comput. Environ. Urban 24: 79-93.

Zerger, A., Warren, G., Hill, P., Robertson, D., Weidemann, A. and Lawton, K. (2009) Can regional-scale conservation planning influence farm-scale actions? $18^{\text {th }}$ World IMACS/ MODSIM Congress. Cairns, Australia. 
PEDRO M. LOURENÇO*, ALFONSO GODINO

Centro de Estudos da Avifauna Ibérica (CEAI), Rua do Raimundo 119, Apartado 535, 7002-506 Évora, Portugal.

\section{NUNO CURADO, FILIPA LOUREIRO, EDUARDO SANTOS}

Liga para a Protecção da Natureza (LPN), Estrada do Calhariz de Benfica 187, 150o-124 Lisboa, Portugal.

*Author for correspondence; e-mail: p.m.g.lourenco@gmail.com

Received 4 November 2012; revision accepted 23 May 2012;

Published online 22 November 2012 